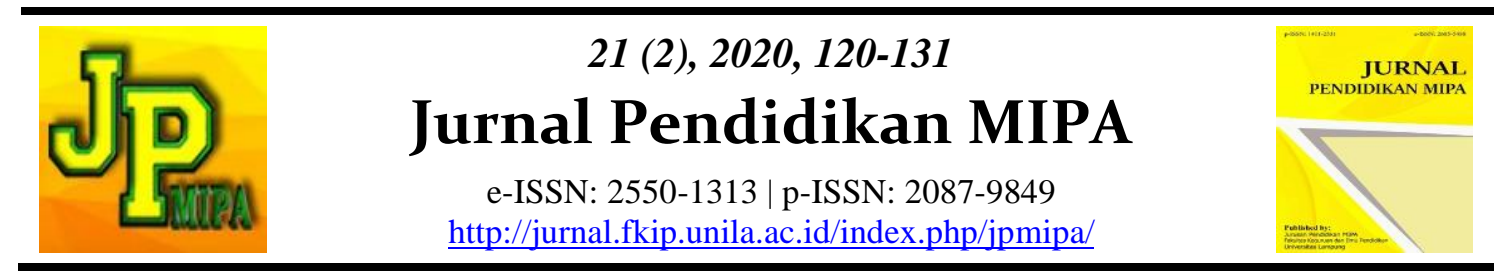

\title{
Students' Learning Motivation in Online Practicum Courses during COVID-19 Pandemic: A Case of Walisongo State Islamic University
}

\author{
Muhammad Yusrun Niam*, Ma'lumatul Fuadiyah, Erna Wijayanti \\ Department of Biology, State Islamic University Walisongo, Indonesia
}

\begin{abstract}
This research aims to identify student learning motivation in online practicum courses during the COVID-19 pandemic. This study used a quantitative survey method toward 117 biology students at the Walisongo State Islamic University. Data were collected using five-point Likert scale questionnaire. The data show that students learning motivation is in good criteria $(75.47 \%)$. The percentage breakdown and criteria for each indicator are as follows: concentration $77.9 \%$ (good), curiosity $81.06 \%$ (very good), enthusiasm $66.67 \%$ (good), independence $82.64 \%$ (very good) ), readiness $77.78 \%$ (good), enthusiasm $66.7 \%$ (good), never give up $72.82 \%$ (good), and confidence $78.21 \%$ (good). This study's result can be used as an evaluation material for designing effective online learning during the COVID-19 pandemic.
\end{abstract}

Keywords: learning motivation, online practicum courses, COVID-19 pandemic.

Abstrak: Penelitian ini bertujuan untuk memberikan gambaran objektif motivasi belajar mahasiswa pada mata kuliah praktikum secara daring di masa pandemi COVID-19, sehingga dapat digunakan sebagai bahan evaluasi untuk merancang pembelajaran daring yang efektif selama pandemi COVID-19. Metode yang digunakan dalam penelitian ini adalah metode survei kuantitatif terhadap 117 orang mahasiswa Biologi di Universitas Islam Negeri Walisongo. Pengumpulan data penelitian menggunakan kuisioner skala Likert. Berdasarkan hasil penelitian ini, dapat disimpulkan bahwa motivasi belajar mahasiswa termasuk ke dalam kriteria baik, dilihat dengan nilai rata-rata dari indikator adalah 75,47\%. Rincian presentase dan kriteria yang dimiliki tiap indikator adalah sebagai berikut: konsentrasi 77,9\% (baik), rasa ingin tahun $81,06 \%$ (sangat baik), semangat 66,67\% (baik), kemandirian 82,64\% (sangat baik), kesiapan $77,78 \%$ (baik), antusias 66,7\% (baik), pantang menyerah 72,82\% (baik), dan percaya diri 78,21 $\%$ (baik).

Kata kunci: motivasi belajar, pembelajaran praktikum daring, pandemi COVID-19.

Muhammad Yusrun Niam et al.

Email: yusrunniam97@gmail.com
DOI: http://dx.doi.org/10.23960/jpmipa/v21i2.pp120-131

Received: 30 September 2020

Accepted: 07 December 2020 


\section{- INTRODUCTION}

The COVID-19 pandemic is endemic throughout the hemisphere. COVID-19 originated from Wuhan, China, and then spread rapidly to various parts of the world. Benvenuto et al. (2020), the transmission of COVID-19 occurred from animals to humans, discovered around November 2019. The SARS-Cov-2 virus that causes COVID19 is a family member of the Coronaviridae virus family. The Coronaviridae family consists of four genera, namely alpha coronavirus, beta coronavirus, gamma coronavirus, and delta coronavirus. Coronaviruses that infect humans are genus alpha coronavirus and beta coronavirus, while gamma coronavirus, and delta coronavirus show infection in fish and birds (Junejo et al., 2020).

Generally, the spread of COVID-19 through droplets happened when coughing/sneezing or in direct contact with patients (Adam \& Walls, 2020). Droplets splashed into the air cause the spread of COVID-19 to be very fast. To respond to the rapid range of COVID-19, the Indonesian government issued the Republic of Indonesia Ministerial Regulation No.9 in 2020. One of the contents of the Ministerial Regulation is to close schools at all levels up to universities. Previously the government also tried to lockdown for 14 days to minimize the spread of COVID-19 (Yunus \& Rezki, 2020). This causes the process of face-to-face learning in the room to be replaced by an online learning process so that the learning process continues (Sintema, 2020). This online learning causes changes in learning patterns, media, and preparation of learning materials for students (United Nations, 2020).

One of the subjects experiencing changes in learning patterns due to adapting to pandemic situations is practicum courses. Practicum courses are subjects that are usually conducted by face to face between students and lecturers in the Laboratory. Practicum courses emphasize the psychomotor aspects, mostly done through laboratory work that aims to train skills (competencies) in specific fields of study. The competency in question is the competence that emphasizes what can be done (practiced) by students and not merely knowledge/theory.

Online learning, which is used as alternative learning in the COVID-19 pandemic era, has forced online practicum activities. This resulted in students' psychomotor competence when taking practical subjects that could not be achieved perfectly (Suganda, 2006). Besides, there are several obstacles in implementing online practicum learning courses such as limited quota, limited IT mastery, a lot of assignments, unstable networks, being late in attending classes because they are not accustomed to using online, and so forth. These obstacles that may occur during online learning can have psychological effects on students, which, if they cannot be controlled, can adversely affect the level of learning motivation (Jamaluddin et al., 2020).

Learning motivation consists of two words, namely, motivation and learning. Motivation is a willingness sourced from internal or external that encourages to do something activity to be achieved (Suprihatin, 2015). Motivation can also explain why someone does a specific thing or target (Cleopatra, 2015). While learning is an activity carried out consciously by allowing changes in mental aspects to gain experience or knowledge (Pane \& Dasopang, 2017). It can be concluded that learning motivation is an internal or external impulse to achieve changes in mental aspects by gaining experience or knowledge. There are eight indicators to assess learning motivation consisting of independence, readiness, enthusiasm, concentration, never giving up, enthusiasm, confidence, and curiosity (Uno, 2007). 
Learning motivation is closely related to learning interest because the right learning motivation has a positive effect on students' interests (Fauziah et al., 2017; Riswanto et al., 2017). Besides, learning motivation has a function of positive correlation to learning outcomes and achievements, because motivation encourages to achieve the desired target (Emda, 2018; Tokan et al., 2018). Therefore, significant research is carried out to provide an objective picture of student learning motivation in online practicum courses during the COVID-19 pandemic. It can be used as an evaluation material to design effective online learning during and after the COVID-19 pandemic.

\section{- METHOD}

\section{Research Design}

This research type is quantitative research. In quantitative research, characteristics are data analysis techniques using quantitative techniques (statistics) objectively (Creswell, 2010). The data collection process was carried out by a survey method with a questionnaire instrument distributed via a google form. This questionnaire will be analyzed using a Likert scale and used to measure the respondents' grade of learning motivation.

\section{Research Instruments}

The instrument used in this study was a questionnaire (see Appendix). The questionnaire consists of 25 questions, which represent 8 indicators of learning motivation, according to Uno (2009). The eight indicators of learning motivation include concentration ( 7 questions), curiosity (4 questions), spirit (2 questions), independence (2 questions), readiness (2 questions), enthusiastic (5 questions), never giving up (1 question) and confident ( 2 questions). The questionnaire calculation used a Likert scale with details: strongly agree answers are given 5 scores, agree answers are given 4 scores, uncertain answers are given 3 scores, disagree answers are given 2 scores, and strongly disagree answers are given 1 score.

\section{Sampling Procedure}

The subjects in this study were 117 students majoring in Biology at the Walisongo State Islamic University in Semarang who received online practicum courses during the COVID-19 pandemic. Subjects were taken by random sampling and succeeded in capturing 83 second semester students and 34 fourth semester students consisting of 98 girls and 19 boys.

\section{Data Analysis}

The questionnaire calculation is done by adding up the answers' total score of strongly agree, agree, uncertain, disagree, and strongly disagree with each respondent. The total score was then converted into a value scale of 1-100 by dividing the observation score by the maximum score then multiplying with $100 \%$. After that, the questionnaire scores were interpreted according to the assessment category by Sugiyono (2015) where scores at intervals of 1-20 fall into the very poor category, scores 21-40 are in the poor category, scores 41-60 are in enough category, score 61-80 is in a good category, and score $81-100$ is in the very good category. 


\section{- RESULT AND DISCUSSION}

The learning motivation survey questionnaire was given to 117 students majoring in Biology at Walisongo State Islamic University Semarang class 2018-2019 who took online practicum courses. The results of each indicator of learning motivation is presented in Figure 1.

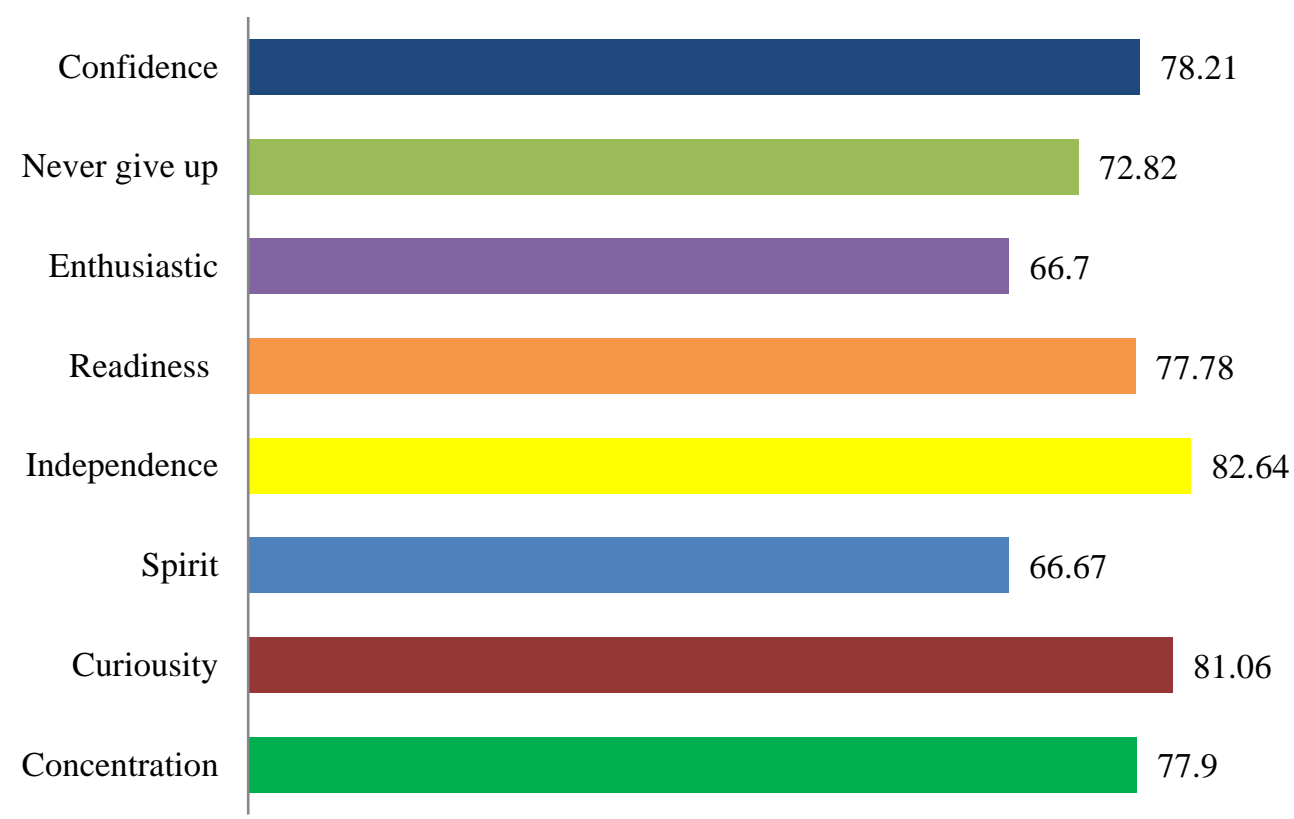

Figure 1. Learning motivation survey result

Based on Figure 1, the highest indicator of learning motivation is on the indicator of independence. At the same time, the lowest indicator is found in the spirit indicator. The following is a description of the survey results based on each indicator of learning motivation.

Table 1. Learning motivation survey result (concentration indicator)

\begin{tabular}{llll}
\hline Indicator & \multicolumn{1}{c}{ Aspect } & Precentage & Criteria \\
\hline & $\begin{array}{l}\text { Follow the practicum seriously. } \\
\text { Understand the instructions from the } \\
\text { lecturer or practicum assistant. } \\
\text { Listen to the explanations of lecturer } \\
\text { or practicum assistant well. }\end{array}$ & & \\
Concentration & $\begin{array}{l}\text { Pay attention to the explanation of the } \\
\text { lecturer or assistant practicum. }\end{array}$ & & \\
& Obey the rule during practicum. & & \\
& Serious in doing the assignment. & & \\
& $\begin{array}{l}\text { Take notes on any material given by } \\
\text { the lecturer or practicum assistant in a } \\
\text { neat notebook. }\end{array}$ & \\
\end{tabular}

High learning motivation in students encourages students to get good grades and abilities in practicum lectures to achieve these goals; students become diligent in learning 
and understanding the material and practicum well. One indicator that is measured to determine the level of student learning motivation is concentration. Aviana and Hidayah (2015) stated that focus on the learning process would provide an understanding and form a flow of thinking to give responses and interpretations of learning. A high concentration of learning in students provides a positive relationship with learning outcomes (Navia and Yulia, 2017).

Several factors affect the level of concentration of each student, Mehralizadeh (2013); Rahiminia et al., (2018); Noviati et al., (2019) states that there are at least two factors that affect the level of concentration, namely internal factors, and external factors. Internal factors come from the students themselves, such as lazy to learn and pay attention to practice, students who are often sleepy, so they are less able to understand the content or are busy with their work. At the same time, external factors come from the environment around students, such as inadequate supporting facilities and infrastructure, quota and signal/network constraints, and the way teachers deliver material that is not interesting and lack understanding. Based on the study results, which can be seen in Table 1., the percentage of student concentration indicators reached $77.96 \%$, which showed that the criteria for student concentration were in a good category.

Table 2. Learning motivation survey result (curiosity indicator)

\begin{tabular}{|c|c|c|c|}
\hline Indicator & Aspect & Precentage & Criteria \\
\hline Curiosity & $\begin{array}{l}\text { Try to ask friends who have } \\
\text { understood when having } \\
\text { diifficulty understanding the } \\
\text { material practicum. } \\
\text { Always ask the lecturer or } \\
\text { practicum assistant about } \\
\text { practicum concept that are } \\
\text { not yet understood. } \\
\text { Try to find out the difficult } \\
\text { lab concepts. } \\
\text { Look for other references that } \\
\text { are appropriate to perfect the } \\
\text { understanding of practicum } \\
\text { material. }\end{array}$ & $81.06 \%$ & Very good \\
\hline
\end{tabular}

The second indicator of learning motivation is curiosity, which can be seen in Table 2. Curiosity is a desire to know better something previously unknown or not yet understood (Hadi \& Permata, 2010). Based on the study results, note that the percentage of curiosity indicators achieved by students is $81.06 \%$, which indicates that the level of curiosity is in very good criteria. Interest shows that students have the motivation to learn in the learning process. Pluck \& Johnson (2011); Gurning et al., (2017); Novelyya (2019) states that students' curiosity influences the success and achievement of understanding in the learning process, so interest needs to be improved. The quantum teaching-learning method and the predict-observe-explain (POE) model can be used as learning methods that can increase curiosity (Pamungkan et al., 2017; Sugiarto et al., 2017).

Wade \& Kidd (2019) explain that curiosity is a metacognitive signal owned by a student. Students' curiosity arises because of a gap in the explanation or confirmation of whether what they guessed was right or wrong. Curiosity is influenced by several factors, 
including knowledge, the novelty of the concept of knowledge presented, familiarity with the topic presented, attention to the material presented, influence (external or internal), and the mental state of students.

Table 3. Learning motivation survey result (spirit indicator)

\begin{tabular}{clcc}
\hline Indicator & \multicolumn{1}{c}{ Aspect } & Precentage & Criteria \\
\hline \multirow{5}{*}{ Spirit } & $\begin{array}{l}\text { Always answer questions } \\
\text { from lectuerer or practicum }\end{array}$ & & \\
& $\begin{array}{l}\text { assistants appropriatly. } \\
\text { Always give an opinion } \\
\text { during the discussion. }\end{array}$ & & Good \\
\hline
\end{tabular}

The third indicator of learning motivation is spirit, which can be seen in Table 3 . The spirit indicator has a percentage value of $66.67 \%$, which shows that students' concentration is in good criteria. Several factors, such as can influence student's spirit for learning are the interest in the science being studied, the orientation or purpose in following the learning process in higher education, the reference or reference facilities such as a library that can be used by students, the weight of lecture material, the method of delivering material and the lecturers' quality while teaching (Anggraini, 2016).

Increased spirit for learning will have good implications for learning outcomes (Sugiarti, 2019). Besides, the spirit of learning can also be influenced by the learning media used as expressed by (Kupczynski et al., (2010); Putri \& Jamna (2019) that learning media has a significant relationship with learning spirit.

Table 4. Learning motivation survey result (independence indicator)

\begin{tabular}{|c|c|c|c|}
\hline Indicator & Aspect & Precentage & Criteria \\
\hline Independence & $\begin{array}{l}\text { Doing their own practicum } \\
\text { report. } \\
\text { Complete practical tasks with } \\
\text { their abilities. }\end{array}$ & $82.64 \%$ & Verygood \\
\hline
\end{tabular}

The fourth indicator is independence in Table 4, which has a percentage of $82.64 \%$ and shows that the indicator of student independence is very good. Freedom of students will positively affect cognitive attitudes, creative mathematical thinking, and mathematical reasoning (Rijjal \& Bachtiar, 2015; Akhdiyat \& Hidayat, 2018; Fajriyah et al., 2019). Learning independence that is owned by students can be one of the things that affect learning success (Suhendri, 2015) so that the learning independence of students can be used to maximize the ability of students without having to depend on teachers/friends (Nuridawani et al., 2015). Learning independence is an independent effort to obtain learning information and learn resources apart from lecturers (Suhendri, 2015).

Table 5. Learning motivation survey result (readiness indicator)

\begin{tabular}{clcc}
\hline Indicator & \multicolumn{1}{c}{ Aspect } & Precentage & Criteria \\
\hline & $\begin{array}{l}\text { Join an online practicum on } \\
\text { time. }\end{array}$ & & \\
Readiness & $\begin{array}{l}\text { Read the practicum } \\
\text { instructions before the } \\
\text { practicum starts. }\end{array}$ & $77.78 \%$ & Good \\
\hline
\end{tabular}


The fifth indicator is readiness, which can be seen in Table 5. The readiness referred to in this research is the readiness of students to take part in the online practicum learning process. Willingness to learn is interpreted as readiness in real terms and readiness in the psychological and material sense. Willingness is an essential factor needed to start an activity, including learning activities. Because by having readiness, anything will be overcome and done smoothly, and the results will be much better (Fatchurrohman, 2011; Engin, 2017; Dangol et al., 2019; Kearney et al., 2019). In this study, the readiness indicator has a $77.78 \%$ percentage, which shows that students have a good readiness to participate in online practicum activities.

Table 6. Learning motivation survey result (enthusiastic indicator)

\begin{tabular}{clcc}
\hline Indicator & \multicolumn{1}{c}{ Aspect } & Precentage & Criteria \\
\hline Enthusiastic & $\begin{array}{l}\text { Interested with the practicum } \\
\text { topic. } \\
\text { Try to answer the lecturer or } \\
\text { assistant question before } \\
\text { another friend answers. }\end{array}$ & $66.7 \%$ & Good \\
\hline
\end{tabular}

The sixth indicator is enthusiasm or encouragement, which can be seen in Table 6. The percentage of enthusiastic indicators achieved by students was $66.7 \%$, which showed that the students' enthusiasm was classified as good. Energy can be interpreted as the existence of excitement, passion, interest, the feeling of pleasure, and massive enthusiasm for something that can cause an interest (Gabryś-Barker, 2014). Research conducted by Serin (2017) and Asvio et al., (2017) proves that passion for learning can influence the achievements of students. Students who have high learning enthusiasm can get higher learning achievement than students who have low learning enthusiasm.

Table 7. Learning motivation survey result (never give up indicator)

\begin{tabular}{clccc}
\hline Indicator & \multicolumn{1}{c}{ Aspect } & Precentage & Criteria \\
\hline $\begin{array}{c}\text { Never give } \\
\text { up }\end{array}$ & $\begin{array}{l}\text { Always be challenged to } \\
\text { understand practical concepts } \\
\text { that are considered difficult. }\end{array}$ & $72.82 \%$ & Good \\
\hline
\end{tabular}

The seventh indicator in learning motivation is never give up, which can be seen in Table 7. Never give up can be interpreted as a defensive attitude to continue to want to achieve what is desired even though it has experienced failure, obstacles, or because of obstacles. This unyielding attitude is essential in learning because an unyielding attitude will make an individual not easily discouraged, always be optimistic, and quickly rise from adversity (Tasmara, 2008). The study results obtained a percentage of $72.82 \%$ for the indicator of never giving up; this shows that the attitude of never giving up students is quite good.

Table 8. Learning motivation survey result (confidence indicator)

\begin{tabular}{clcc}
\hline Indicator & \multicolumn{1}{c}{ Aspect } & Precentage & Criteria \\
\hline Confidence & $\begin{array}{l}\text { Try to answering a friend's } \\
\text { question. }\end{array}$ & $78.21 \%$ & Good \\
\hline
\end{tabular}


The last indicator of learning motivation is self-confidence, which can be seen in Table 8 . Based on the results of the study obtained a percentage of $78.21 \%$ for indicators of confidence which shows that the level of student confidence is quite good. An attitude of trust is a person's belief in all aspects of their strengths so that someone feels able to achieve their goals in life. According to Hakim (2005); Greenacre (2014), there are several characteristics of individuals with proportional self-confidence: calmness in doing something, being able to adapt to all situations, efficiently communicating and always reacting positively in responding to a problem. Self-esteem has a significant relationship with learning motivation. A good level of confidence shows that students' motivation to learn is also quite good (Topcu et al., 2016).

Based on the analysis of student learning motivation in online practicum subjects during the COVID-19 pandemic, an average percentage of $75.47 \%$ was obtained, which indicates that the level of student learning motivation is relatively good. The existence of a COVID-19 pandemic that is sweeping the world does not impede learning motivation in participating in online practicum learning. Through online learning, students can build and create student knowledge independently through various media pages (websites) that can be accessed via the internet or by establishing discussion platforms on social media (Kemendikbud, 2016). Besides, students have the freedom of learning time because all learning processes, such as accessing teaching materials, the process of discussion, and work assignments, can be done online (Jez \& Wassmer, 2015; Isman, 2016). Therefore, in the future lecturers need to design online practicum activities that are tailored to student characteristics, instructor characteristics, quality of institutions and services, infrastructure and quality of systems, quality of courses and information (Conditioning et al., 2019), so that students' learning motivation can increase and learning objectives can be achieved with a maximum.

\section{- CONCLUSION}

From the research results, we conclude that the level of learning motivation of Biology students at UIN Walisongo Semarang is in a good category seen by the average value of the indicator is $75.47 \%$. Two factors influence student learning motivation, namely, internal factors and external factors. Internal factors exist in students, such as interest in lessons and orientation or study objectives. At the same time, external factors are factors from outside the student that affect learning motivation, such as the lecturers' quality, the course material's weight, the lecture method, the lecture infrastructure's condition, the network, and the environment.

\section{- REFERENCES}

Adams, J. G. \& Walls, R. M. (2020). Supporting the health care workforce during the COVID-19 global epidemic. Jama, 323(15), 1439-1440.

Akhdiyat, A. M., \& Hidayat, W. (2018). Pengaruh kemandirian belajar matematik siswa terhadap kemampuan berpikir kreatif matematis siswa SMA [The effect of students 'mathematical learning independence on high school students' mathematical creative thinking skills]. Jurnal Pembelajaran Matematika Inovatif, 1(6), 10451054.

Anggraini, I. S. (2016). Motivasi belajar dan faktor-faktor yang berpengaruh: sebuah kajian pada interaksi pembelajaran mahasiswa [Learning motivation and influencing factors: an assessment of student learning interactions]. Premiere Educandum: Jurnal Pendidikan Dasar dan Pembelajaran, 1(02). 
Asvio, N. (2017). The influence of learning motivation and learning environment on undergraduate students' learning achievement of management of islamic education, Study Program of Iain Batusangkar in 2016. Noble International Journal of Social Sciences Research, 2(2), 16-31.

Aviana, R., \& Hidayah, F. F. (2015). Pengaruh tingkat konsentrasi belajar siswa terhadap daya pemahaman materi pada pembelajaran kimia di SMA Negeri 2 Batang [The effect of the level of student concentration on the understanding of the material in learning chemistry at SMA Negeri 2 Batang]. Jurnal Pendidikan Sains, 3(1), 30-33.

Benvenuto, D., Giovanetti, M., Ciccozzi, A., Spoto, S., Angeletti, S., \& Ciccozzi, M. (2020). The 2019-new coronavirus epidemic: Evidence for virus evolution. Journal of Medical Virology, 92(4), 455-459.

Cleopatra, M. (2015). Pengaruh gaya hidup dan motivasi belajar terhadap prestasi belajar matematika [The influence of lifestyle and learning motivation on mathematics learning achievement]. Formatif: Jurnal Ilmiah Pendidikan MIPA, $5(2)$.

Creswell, J. W., \& Creswell, J. D. (2017). Research design: Qualitative, quantitative, and mixed methods approaches. Sage publications.

Dangol, R., \& Shrestha, M. (2019). Learning readiness and educational achievement among school students. The International Journal of Indian Psychology, 7(2), 467476.

Emda, A. (2018). Kedudukan motivasi belajar siswa dalam pembelajaran [Position of student motivation in learning]. Lantanida Journal, 5(2), 172-182.

Engin, M. (2017). Analysis of students' online learning readiness based on their emotional intelligence level. Universal Journal of Educational Research, 5, 32-40.

Fajriyah, L., Nugraha, Y., Akbar, P., \& Bernard, M. (2019). Pengaruh Kemandirian Belajar Siswa SMP Terhadap Kemampuan Penalaran Matematis [The effect of independent junior high school student learning on mathematical reasoning ability]. Journal on Education, 1(2), 288-296.

Fatchurrohman, R. (2011). Pengaruh motivasi berprestasi terhadap kesiapan belajar, pelaksanaan prakerin dan pencapaian kompetensi mata pelajaran produktif [The influence of achievement motivation on learning readiness, implementation of internship and competency attainment of productive subjects]. Innovation of Vocational Technology Education, 7(2).

Fauziah, A., Rosnaningsih, A., \& Azhar, S. (2017). Hubungan antara motivasi belajar dengan minat belajar siswa kelas IV SDN Poris Gaga 05 kota Tangerang [The relationship between learning motivation and learning interest of fourth grade students of SDN Poris Gaga 05, Tangerang city]. Jurnal JPSD, 4(1), 47-53.

Gabryś-Barker, D. (2014). Success: From filure to failure with enthusias. Studies in Second Language Learning and Teaching, 4(2), 301-325.

Greenacre, L., Tung, N.M. \& Chapman T. (2014). Self confidence and the ability to influence. Academy of Marketing Studies Journal, 18(2), 169-180.

Gurning, B., \& Siregar, A. (2017). The effect of teaching strategies and curiosity on students' achievement in reading comprehension. English Language Teaching, 10(11), 191-198.

Hadi, S., \& Permata, N. (2010). Kamu bisa jadi ilmuan [You can be a scientist]. Jakarta: Perca. 
Hakim, T. (2005). Mengatasi rasa tidak percaya diri [Overcoming insecurities]. Jakarta: Puspa Swara.

Isman, M. (2016). Pembelajaran moda dalam jaringan (moda daring) [Online mode learning]. The Progressive and Fun Education Seminar. ISBN: 978-602-361-0457

Jamaluddin, D., Ratnasih, T., Gunawan, H., \& Paujiah, E. (2020). Pembelajaran daring masa pandemik Covid-19 pada calon guru: Hambatan, solusi dan proyeksi [Online learning during the Covid-19 pandemic for prospective teachers: Barriers, solutions and projections]. LP2M UIN SGD.

Jez, S. J., \& Wassmer, R. W. (2015). The impact of learning time on academic achievement. Education and Urban Society, 47(3), 284-306.

Junejo, Y., Ozaslan, M., Safdar, M., Khailany, R. A., Rehman, S., Yousaf, W., \& Khan, M. A. (2020). Novel SARS-CoV-2/COVID-19: Origin, pathogenesis, genes and genetic variations, immune responses and phylogenetic analysis. Gene reports, 20 , 100752.

Kearney, W. S., \& Garfield, T. (2019). Student readiness to learn and teacher effectiveness: Two key factors in middle grades mathematics achievement. RMLE Online, 42(5), 1-12.

Kemendikbud, D. G. (2016). Buku Pengangan Pelatihan Instruktur Nasional/Mentor Guru Pembelajar [Handbook of National Instructor / Teacher Learners Training]. Jakarta: Kemendikbud.

Kementrian Kesehatan. (2020). Peraturan Menteri Kesehatan Republik Indonesia Nomor 9 Tahun 2020 Tentang Pedoman Pembatasan Sosial Berskala Besar Dalam Rangka Percepatan Penanganan Corona Virus Disease 2019 (Covid-19) [Regulation of the Minister of Health of the Republic of Indonesia Number 9 of 2020 concerning Guidelines for Large-Scale Social Restrictions in the Context of Accelerating the Handling of Corona Virus Disease 2019 (Covid-19)]. Retrieved from http://hukor.kemkes.go.id/uploads/produk hukum/PMK_No_9 Th_2020_ttg_Pe doman_Pembatasan_Sosial_Berskala_Besar_Dalam_Penanganan_COVID-19.pdf

Kupczynski, L., Ice, P., Wiesenmayer, R., \& McCluskey, F. (2010). Student perceptions of the relationship between indicators of teaching presence and success in online courses. Journal of Interactive Online Learning, 9(1).

Mehralizadeh, S., Ghorbani, R., Zolfaghari, S., Shahinfar, H., Nikkhah, R., \& Pourazizi, M. (2013). Factors affecting student concentration in classroom: Medical students' viewpoints in semnan university of medical sciences. Iranian Journal of Medical Education, 13(8), 663-671.

Navia, Y., \& Yulia, P. (2017). Hubungan disiplin belajar dan konsentrasi belajar terhadap hasil belajar matematika siswa [The relationship between learning discipline and learning concentration on students' mathematics learning outcomes]. PYTHAGORAS: Jurnal Program Studi Pendidikan Matematika, 6(2).

Novelyya, S. (2019). Pengaruh karakter rasa ingin tahu siswa terhadap hasil belajar mata pelajaran IPA Fisika di SMP Negeri 08 Muaro Jambi. Briliant: Jurnal Riset dan Konseptual, 4(2), 174-181.

Noviati, R., Misdar, M., \& Adib, H. S. (2019). Pengaruh lingkungan belajar terhadap tingkat konsentrasi belajar siswa pada mata pelajaran akidah akhlak Di MAN 2 Palembang. Jurnal PAI Raden Fatah, 1(1), 1-20.

Nuridawani, N., Munzir, S., \& Saiman, S. (2015). Peningkatan kemampuan penalaran matematis dan kemandirian belajar siswa Madrasah Tsanawiyah (MTs) melalui 
pendekatan Contextual Teaching and Learning (CTL). Jurnal Didaktik Matematika, 2(2).

Pamungkas, M. S. H., Mulyani, S., \& Saputro, S. (2017). Penerapan model pembelajaran poe dengan metode praktikum untuk meningkatkan rasa ingin tahu dan prestasi belajar kimia siswa [The application of the POE learning model with the practical method to increase students' curiosity and chemistry learning achievement]. Jurnal Penelitian Pendidikan, 20(1), 46-60.

Pane, A., \& Dasopang, M. D. (2017). Belajar dan pembelajaran [learn and learning]. Fitrah: Jurnal Kajian Ilmu-Ilmu Keislaman, 3(2), 333-352.

Pangondian, R. A., Santosa, P. I., \& Nugroho, E. (2019, February). Faktor-faktor yang mempengaruhi kesuksesan pembelajaran daring dalam Revolusi Industri 4.0 [Factors affecting the success of online learning in the Industrial Revolution 4.0]. In Seminar Nasional Teknologi Komputer \& Sains (SAINTEKS), 1(1).

Pluck, G., \& Johnson, H. L. (2011). Stimulating curiosity to enhance learning. GESJ: Education Sciences and Psychology, 2.

Putri, N. Z., \& Jamna, J. (2019). Hubungan penggunaan media pembelajaran dengan semangat belajar peserta pelatihan Bahasa Jepang [The relationship between the use of learning media and the enthusiasm of learning Japanese language training participants]. JFACE: Journal of Family, Adult, and Early Childhood Education, 1(3), 329-337.

Rahiminia, E., Yazdani, S., \& Rahiminia, H. (2019). Factors affecting concentration and attendance in the classroom from students' point of view in Qom University of Medical Sciences (2018). Educational Research in Medical Sciences, 8(2).

Rijal, S., \& Bachtiar, S. (2015). Hubungan antara sikap, kemandirian belajar, dan gaya belajar dengan hasil belajar kognitif siswa [The relationship between attitudes, independent learning, and learning styles with students' cognitive learning outcomes]. Jurnal Bioedukatika, 3(2), 15-20.

Riswanto, A., \& Aryani, S. (2017). Learning motivation and student achievement: description analysis and relationships both. The International Journal of Counseling and Education, 2(1), 42-47.

Serin, H. (2017). The role of Passion in Learning and Teaching. International Journal of Social Sciences \& Educational Studies, 4(1), 60.

Sintema, E. J. (2020). Effect of COVID-19 on the performance of grade 12 students: Implications for STEM education. Eurasia Journal of Mathematics, Science and Technology Education, 16(7), em1851.

Suganda, T. (2006). Panduan penjaminan mutu Universitas Pendidikan Indonesia [Guide to quality assurance of the Indonesian University of Education]. Bandung: UPI Bandung.

Sugiarti, S. (2019). Meningkatkan semangat belajar siswa melalui metode demonstrasi dan eksperimen [Increase students' enthusiasm for learning through demonstration and experimental methods]. Jurnal Pena Edukasi, 5(4), 287-292.

Sugiarto, D. H., Utomo, S. B., Saputro, A. N. C., \& Paerah, P. (2017). Penerapan model pembelajaran quantum teaching untuk meningkatkan rasa ingin tahu dan prestasi belajar siswa pada materi koloid kelas XI IPA SMA Negeri 3 Boyolali Tahun Pelajaran 2015/2016 [Application of the quantum teaching learning model to increase curiosity and student achievement in colloid material in class XI IPA SMA Negeri 3 Boyolali Academic Year 2015/2016]. Jurnal Pendidikan Kimia Universitas Sebelas Maret, 6(1), 24-30. 
Sugiyono, S. (2015). Metode penelitian pendidikan pendekatan kuantitatif, dan $R \& D$ [Quantitative approach educational research methods, and $R \& D$ ]. Bandung: Alfabeta.

Suhendri, H. (2015). Pengaruh metode pembelajaran problem solving terhadap hasil belajar matematika ditinjau dari kemandirian belajar. Formatif: Jurnal Ilmiah Pendidikan MIPA, 3(2).

Suprihatin, S. (2015). Upaya guru dalam meningkatkan motivasi belajar siswa [The teacher's efforts to increase student motivation]. Jurnal Pendidikan Ekonomi UM Metro, 3(1), 73-82.

Tasmara, T. (2002). Membudayakan etos kerja Islami. Jakarta: Gema Insani.

Tokan, M. K., \& Imakulata, M. M. (2019, February). Correlation between motivation and learning behavior with learning achievement: A case study on the Biology Education Department Faculty of Teacher Training and Education University of Nusa Cendana. In Journal of Physics: Conference Series (Vol. 1157, No. 4, p. 042128). IOP Publishing.

Topçu, S., \& Leana-Taşcilar, M. Z. (2018). The role of motivation and self-esteem in the academic achievement of Turkish gifted students. Gifted Education International, 34(1), 3-18.

United Nations. (2020). Policy Brief: The Impact of on children. USA: United Nations.

Uno, H. B. (2007). Teori motivasi dan pengukurannya: Analisis di bidang pendidikan (Cetakan ketiga) [Motivation theory and its measurement: Analysis in education (Third printing)]. Jakarta: Bumi Akasara.

Wade, S., \& Kidd, C. (2019). The role of prior knowledge and curiosity in learning. Psychonomic bulletin \& review, 26(4), 1377-1387.

Yunus, N. R., \& Rezki, A. (2020). Kebijakan pemberlakuan lock down sebagai antisipasi penyebaran Corona Virus Covid-19 [The lock down implementation policy is to anticipate the spread of the Corona Virus Covid-19]. Salam: Jurnal Sosial dan Budaya Syar-i, 7(3), 227-238. 